\title{
Appropriate Competencies and Skillset for Graphic DesignGraduates: e-Portfolio
}

\author{
Wan Zamani Wan Zakaria ${ }^{1}$, Norfadilah Kamaruddin ${ }^{1}$, Roslaili Anuar ${ }^{2}$ \\ 1 Faculty of Art and Design, Universiti Teknologi MARA, 40450 Shah Alam, Selangor, Malaysia \\ 2 Faculty of Education, Universiti Teknologi MARA, 42300 Puncak Alam, Selangor, Malaysia \\ wanzfssr@uitm.edu.my¹,norfadilah@uitm.edu.my²,rosla206@uitm.edu.my3 \\ Tel:+60193406774
}

\begin{abstract}
Emerging technological environments and social media networking have led many design companies in Malaysia to select qualified employees with the required skillset. Towards this, graphic design graduates must have an individual portfolio but placing them for a job with relevant skills requirements is not easy. Thus, this paper aims to ascertain the competencies and skillset required by employers. The researcher analyzed 30 internet job advertising to determine three key competencies and skill sets connected with the study's objectives. The findings are highly beneficial for the Graphic Design graduates towards meeting the employers' expectations.
\end{abstract}

Keywords: Competencies; Skillset, Graphic design; e-Portfolio

eISSN: 2398-4287 @ 2021. The Authors. Published for AMER ABRA cE-Bs by e-International Publishing House, Ltd., UK. This is an open access article under the CC BYNCND license (http://creativecommons.org/licenses/by-nc-nd/4.0/). Peer-review under responsibility of AMER (Association of Malaysian Environment-Behaviour Researchers), ABRA (Association of Behavioural Researchers on Asians) and cE-Bs (Centre for Environment-Behaviour Studies), Faculty of Architecture, Planning \& Surveying, Universiti Teknologi MARA, Malaysia.

DOI: https://doi.org/10.21834/ebpj.v6iSl6.3045

\subsection{Introduction}

The rapid changes in creative industries were giving significant challenges for most graphic design graduates. Recruitment of newly graduated graphic designers may be a thorough yet exciting process, as Careerplanner.com (1997-2021) estimated that recruitment for graphic designers will grow at a 5\% pace between 2016 and 2026, almost as fast as the average for all occupations. Within these scenarios, the emerging technological environment and social media networking for the last few decades have led many design companies to become competitive in selecting qualified design employees who could perform the required skill set and expertise. With the dynamic impact and intense evolution of the internet, companies have used social media platforms to recruit online. Regardless of specifying the job skillset for the posts of graphic designers, tracking the right candidates' competencies through their digital portfolios suitable to the skill requirements is still relatively low (Abd-Wahab et al. (2016); Careerplanner.com, 2021; Cheung, 2016). Nevertheless, there is also the case in which information and requirement are sometimes unclear to what employers want and value in an applicant's portfolio. In reverse, the graduates are also uncertain in their career path to comply with what employers expect as posted in their advertisements. In addressing the situations, the objective of this study is to identify the competencies and skillset required by employers through an analysis of online job advertisements. Additionally, this study intends to investigate how the student's skill competencies are linked to what future employers believe in the value of e-portfolio reflects career credentials. The study's outcomes would be fundamental guidelines for graphic graduate students to prepare digital portfolios that match the designer position requirements.

eISSN: 2398-4287 @ 2021. The Authors. Published for AMER ABRA cE-Bs by e-International Publishing House, Ltd., UK. This is an open access article under the CC BYNCND license (http://creativecommons.org/licenses/by-nc-nd/4.0/). Peer-review under responsibility of AMER (Association of Malaysian Environment-Behaviour Researchers), ABRA (Association of Behavioural Researchers on Asians) and cE-Bs (Centre for Environment-Behaviour Studies), Faculty of Architecture, Planning \& Surveying, Universiti Teknologi MARA, Malaysia.

DOI: https://doi.org/10.21834/ebpj.v6iSl6.3045 


\subsection{Literature Review}

In Malaysia, most job agencies nowadays are preferred to use online platforms for posting job recruitment. Previously, the most popular online platform was a website including Jobstreet.com, Jobs Malaysia, Job Majestic, Best Jobs PartTimePost.com, Freelancing.my, and Remotelah. Therefore, with the rapid changes in creative industries, many job agencies have moved to other platforms such as social media, which reported that almost $92 \%$ of employers use social media to screen and discover high-quality candidates (Heller \& Fernandes, 2004; Morrison, 2015). Using social media platforms such as Facebook, Instagram, Twitter, and Linkedln is also popular in hiring professionals (Heller \& Fernandes, 2004). Essentially, these online platforms provide access to a broader audience that enables various organizations to reach potential candidates based on a specific job description. As Facebook becomes one of the world's largest and most popular social network platforms (Muller, 2021) that are easily accessible by job seekers through intelligent mobile devices, most employers find it convenient to advertise job vacancies in their organizations. Figure 1 exhibits two samples of recent job advertisements for graphic designers through Facebook sites.

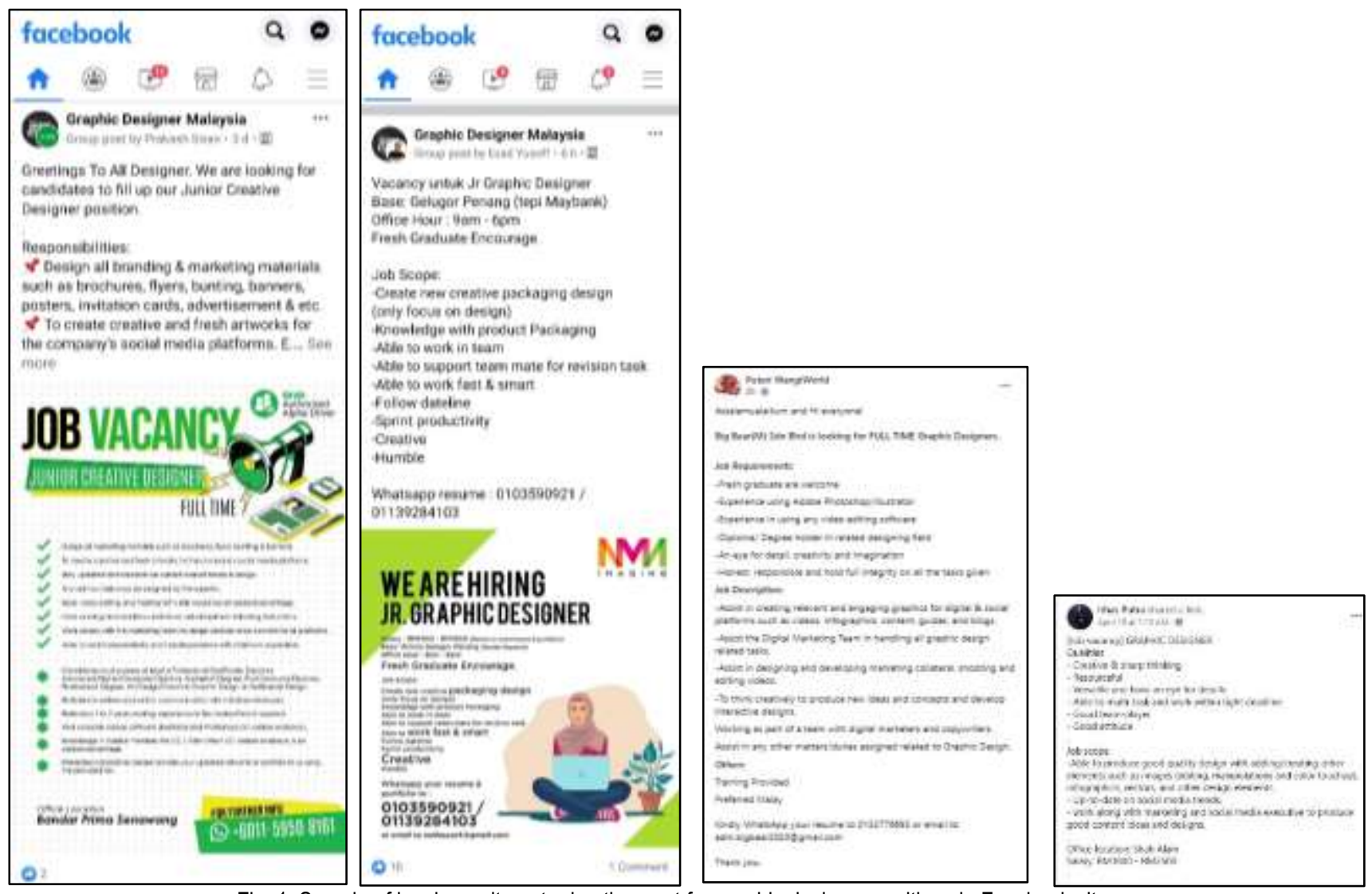

Fig. 1: Sample of local recruitment advertisement for graphic designer positions in Facebook sites.

According to previous research, most businesses use skills and academic performance as essential factors for selecting prospective employees. Employers utilize academic grades and aptitude to determine how students have completed their degrees and how educated they are in their fields of study, according to Pool and Sewell (2007). Potential employers primarily offer job opportunities to students with vital academic records, which occurs even before they graduate. Academic success does not reflect a student's willingness to adapt and integrate into the workplace. As a result, the students' soft skills will be examined and verified during the evaluation and selection process. Thus, mastery of the needed competencies leads to effective job performance. In professional design practice, effective job performance is the achievement of specified job results through specific competencies while meeting current trends and job expectations (Chiang, Idris \& Chuen, 2019).

On the other hand, an e-Portfolio is the tool to showcase students' talent and work that can be demonstrated during their academic years while providing access to employers and other stakeholders for viewing (Mohamad, Embi \& Nordin, 2016). Chang (2019) stated that creating an e-Portfolio showcase demonstrates the job applicant's learning experiences and research projects in a broader context that directly exhibits prior artwork or other work in progress. Accordingly, Lieven (2014) claimed that the e-Portfolio showcase sets a two-way communication system that allows mutual understanding of competencies both from the perspective of job seekers and employers. This claim believed through e-portfolio, students can enhance their ability and critically reflect on their vital skills, especially when employers can constantly view their work achievements concerning their developmental goals. Furthermore, Hinton (2017) discovered that almost $65 \%$ of employers accept that ePortfolio provides better applicants skills and abilities in assisting through the hiring and screening process, which 
constantly describes the potential candidate experience. Other reasons include ease of access to information, providing a better overall picture of an applicant, giving a better understanding of an applicant's skills and abilities, and assisting with the hiring and screening process to provide more information about the applicant's educational experience.

Moreover, the use of an e-Portfolio would benefit the students from many perspectives. As stated by Watty and McKay (2016), providing the evidence of skills in e-Portfolio helps increase the opportunity for future employers to source the best candidate in a broader context. Completely, graduates' e-Portfolio should contain specific items as a piece of evidence and background that relevant to the job application, such as applicants critiquing something, evidence of learning, progress, thinking, and judgment; and information presented more visually. Thus, an e-Portfolio provides students with creative options to transfer their experiences in interactive and meaningful visuals that indicate their design skills level.

\subsection{Methodology}

The researcher conducted a systematic document review in gathering online job advertisements collected from Facebook. The objective of the study is to identify graphic graduate digital portfolio as an employability skills requirement that was listed based on three primary means of competencies : (1) competencies and transferable skill (what to deliver), (ii) knowledge and skills (to know), and (iii) personal characteristic (to have).

As a profiling method, the three competencies of graphic design graduates in their e-portfolio and data from job advertisements were collected and compiled according to categories (job responsibility, job requirement and scope). These categories of competencies connect to what employers (as analyzed from Facebook job requirements) demanded. These data are thematically analyzed to ascertain an initial set of patterns on what employers require from graphic design applicants according to a job specification based on the current review of practices advertised online for graphic designers' job placement. The analysis further expanded through content analysis of the data set, which provides a structure by examining the applicant's skills, knowledge and abilities on how they critically reflect their design skills in the digital portfolio presentation for employment. However, some employers may anticipate a different set of requirements from the candidate's background of knowledge and skills as advertised. Still, the most frequently cited competence area selected was relevant to the experience of graphic design abilities.

There are three stages of data collection and analysis procedure applied to achieve the objectives. The first stage involved a compilation of online job advertisements from Facebook. The second stage is about comparative analysis of the data revealed from the online job advertisement collection towards three primary means of competencies: skills, knowledge, and abilities. Finally, the findings are categorized accordingly with the three major competency standards.

\subsection{Findings}

A total of 30 online job advertising randomly gathered from Facebook sites over six months. These job adverts are placed online by numerous firms seeking to hire a graphic designer. The frequency of those 30 online job advertisements has been screened thoroughly according to the three primary means of competencies. As established in an extensive literature, three necessary competencies as the basis for the analysis were selected, which are (1) competencies and transferable skills (what to deliver), (ii) knowledge and skills (to know), and (iii) personal characteristic (to have). These three significant competencies represent three different domains, namely, (i) job responsibilities, (ii) job requirements, and (iii) job scope. The essential competencies represent in Table 1 below.

\begin{tabular}{|c|c|c|}
\hline $\begin{array}{l}\text { Competence and } \\
\text { transferable skill } \\
\text { (what to deliver) }\end{array}$ & $\begin{array}{l}\text { Knowledge and Skills } \\
\text { (to know) }\end{array}$ & $\begin{array}{c}\text { Personal Characteristic } \\
\text { (to have) }\end{array}$ \\
\hline Job Responsibilities & Job Requirements & Job scope \\
\hline Design digital works & Creative & Working experience \\
\hline $\begin{array}{l}\text { Creative concepts and } \\
\text { visuals }\end{array}$ & Technical design skills & Able to work under pressure \\
\hline \multirow[t]{2}{*}{ Photo manipulation } & $\begin{array}{l}\text { Software design skills } \\
\quad \text { Video editing } \\
\text { Knowledge of design } \\
\text { elements }\end{array}$ & $\begin{array}{c}\text { Team oriented } \\
\text { Motivation } \\
\text { Versatile and adaptable }\end{array}$ \\
\hline & Social media expert & $\begin{array}{l}\text { Passionate towards design } \\
\text { Independent and hardworking }\end{array}$ \\
\hline
\end{tabular}

The first competency refers to the job responsibilities, which indicates the convertible skill that is more on what designer should understand the job duties. Secondly, the prerequisites for creative, technical and software design talents. It represents digital design, unique concepts and aesthetics, and picture modification skills. The third competency concerns the scope of employment, which combines designer job experience and attitudes.

According to an analysis of the content of online job adverts, employers have recognized a variety of abilities as vital for graphic graduates. The data analysis results are in Table 2. 
Table 2. Tabulated data of digital portfolio employability skill requirement by companies in online advertisement

\begin{tabular}{clc}
\hline \multicolumn{1}{c}{ Competencies } & \multicolumn{1}{c}{ Domain } & $\begin{array}{c}\text { Percent } \% \\
\mathrm{~N}=14\end{array}$ \\
\hline Competence and transferable skill & Design digital works & 93.3 \\
(what to deliver) & Creative concepts and visuals & 66.6 \\
& Photo manipulation & 30 \\
Knowledge and Skills & Creative & 90 \\
(to know) & Technical design skills & 93.3 \\
& Software design skills & 100 \\
& Video editing & 16.6 \\
& Knowledge of design elements & 13.3 \\
Personal Characteristic & Social media expert & 20 \\
(to have) & Working experience & 23.3 \\
& Able to work under pressure & 36.6 \\
& Team oriented & 73.3 \\
& Motivation & 33.3 \\
& Versatile and adaptable & 10 \\
& Passionate towards design & 63.3 \\
& Independent and hardworking & 86.6 \\
\hline
\end{tabular}

Data demonstrates that most companies recognize the value of possessing transferrable skills, knowledge, and a solid personal attitude. Almost all domains for each competency are equipped and scored higher. Below is the results of each competency with each domain's score (Table 3, Table 4 and Table 5).

\subsection{Competencies 1: Competence and transferable skill (what to deliver)}

Table 3. The score for each domain of transferable skills

\begin{tabular}{clc}
\hline Competencies & \multicolumn{1}{c}{ Domain } & Percent \% \\
& & $\mathrm{N}=14$ \\
\hline Competence and transferable skill & Design digital works & 93.3 \\
(what to deliver) & Creative concepts and visuals & 66.6 \\
& Photo manipulation & 30 \\
\hline
\end{tabular}

Although the requirement for candidates to demonstrate skills in photo manipulation is only at $30 \%$, it is interesting to know that employers are considering this skill. By referring to Table 3, on the transferable skill required from the graphic design graduates, the analysis exposed $93.3 \%$ of the employers as are necessary for talents who can design digital works. This result is highly substantial as the design industry is advancing with cutting-edge digital technologies. Meanwhile, the ability to deliver creative concepts and visual are expected at only $66.6 \%$ by employers. It advocates that employers already expect that design students should readily be conceptually and visually creative to be involved in the field as expected in the design field.

\subsection{Competencies 2: Knowledge and Skills (to know)}

Table 4. The score for each domain of knowledge and skills

\begin{tabular}{clc}
\hline \multicolumn{1}{c}{ Competencies } & \multicolumn{1}{c}{ Domain } & Percent \% \\
$\mathrm{N}=14$ \\
\hline Knowledge and Skills & Creative & 90 \\
(to know) & Technical design skills & 93.3 \\
& Software design skills & 100 \\
& Video editing & 16.6 \\
& Knowledge of design elements & 13.3 \\
& Social media expert & 20 \\
\hline
\end{tabular}

Table 4 shows the result from the analysis, which established that most employers expect the candidate for the graphic designer post to demonstrate their competencies in delivering creative works through a digital platform, which scored $100 \%$ of the analysis established from software design skill. Candidates for the graphic designer post should also express their competencies in delivering creative works and should have applied knowledge in their skillset, particularly technical design skills, with a score of $93.3 \%$ analysis data on online job advertisements. The results indicated that $90 \%$ requirement for candidates to be creative. Although skills in social media, video editing, and design elements are relatively low, these skills are relevant in digital design.

\subsection{Competencies 3: Personal Characteristic (to have)}

Table 5. The score for each domain of Personal Characteristic

\begin{tabular}{clc}
\hline Competencies & \multicolumn{1}{c}{ Domain } & Percent \% \\
& \multicolumn{1}{c}{ N=14 } \\
\hline Personal Characteristic & Working experience & 23.3 \\
(to have) & Able to work under pressure & 36.6
\end{tabular}




$\begin{array}{lc}\text { Team oriented } & 73.3 \\ \text { Motivation } & 33.3 \\ \text { Versatile and adaptable } & 10 \\ \text { Passionate towards design } & 63.3 \\ \text { Independent and hardworking } & 86.6\end{array}$

Essentially, soft-skill abilities are also crucial in recruiting new talents, and it is interesting to identify that the list for the requirement is substantially varied. Table 5 explains that most employers (86.6\%) look for independent and hardworking applicants but can still be team players $(73.3 \%)$. It is also crucial that a team player needs to be passionate about design work $(63.3 \%)$ and able to handle pressure $(36.6 \%)$ while maintaining motivation (33.3\%). Only $23.2 \%$ of employers seek applicants with working experience. It may be because the design is also an academic activity in which new graduates should have essential experiences. Meanwhile, $10 \%$ of the advertisements require that applicants should be versatile and adaptable.

Based on data results from the analysis, it suggested that individual skillset by each candidate for graphic design post is the main requirement asked by the employers. Based on the results shown, most employers focused on technical design skills and digital design. Indeed, the analysis also revealed that some critical skills such as software design and technologies are in high demand, requiring graphic graduates to acquire a wide range of specific skills relevant to the industry. Importantly, this study lays the foundation for a more profound knowledge of graphic graduates' critical competencies as they prepare for industrial needs. The skills listed in the competencies list could serve as the fundamentals for identifying core competencies required from graphic graduates. With the pressure of the current of IR4.0, each graphic graduate should be skillful in designing and critical in theory, particularly in problem-solving. Thus, each institution that intends to have a graphic design program should provide the students with the appropriate design tools to assist students in developing the necessary skills in preparing them for the working world.

\subsection{Discussion}

Job vacancy advertisements for graphic design would usually indicate specific criteria and the requisite competencies from applicants, supplemented with work experience and personal characteristics with educational and professional credentials. Meanwhile, an e-Portfolio is a tool to showcase students' talent and work during their study time. There are a few suggestions for future study that can be examined for the e-portfolio by graphic graduates to determine the relevant content to meet the demands of the industry. This is to guarantee that the e-portfolio has values that conform with online advertising standards. As a result, it is suggested that a guideline be developed to ensure that graphic design graduates will be adequately prepared for work in the design industry.

\subsection{Conclusion \& Recommendations}

While numerous classification schemes were adopted to classify graduate capabilities, common knowledge included academic qualifications and personal identity. As design practices progress with the new digital platform, graphic designers need to get accustomed to the technologies and develop new skills and competencies to stay relevant in the job market. This study has identified the list of abilities employers highly value and asked from graphic design graduates'. As this study is a foundation to the preliminary research undergoing within the graphic design graduates, further research on models and theory could discuss and expand for a more comprehensive approach on a digital portfolio that includes valuable employability requirements.

\section{Acknowledgment}

The authors would like to extend their appreciation to the Dean, Faculty of Art \& Design, UiTM Puncak Alam Campus, granting the research conducted among the graphic design students.

\section{References}

Abd-Wahab, S. R. H., Che-Ani, A. I., Johar, S., Ismail, K., \& Abd-Razak, M. Z. (2016). ePortfolio: A Descriptive Survey for Contents and Challenges. International Journal of Emerging Technologies in Learning, 11(1).

Careerplanner.com Inc (1997-2021). The Job Outlook for Graphic Designers. Article retrieved from https://job-outlook.careerplanner.com/Graphic-Designers.cfm

Chang, C. N., Patterson, C. A., Lavadia, C., Fowler, D., \& Arroyave, R. (2019, June). Showcasing Interdisciplinary Capabilities: Employers' Perceptions on Reflective ePortfolios. In 2019 ASEE Annual Conference \& Exposition.

Cheung, B. P. S. (2016). Professional Graphic Design Knowledge in Hong Kong: From Graduate to Professional. Communication Design, 4(1-2), 21-40. https://doi.org/10.1080/20557132.2016.1275476

Chiang, W. S., Idris, M. Z., \& Chuen, T. W. (2019).Development of A Model and Instrument for Competency Assessment of Graphic Design Graduates in Malaysia: A Conceptual Framework. International Journal of Education, Psychology of Counselling. 4 (24). 54-68.

Heller, S \& Fernandes, T. (2004). Becoming a Graphic Designer: A Guide to Careers in Design (3rd ed.). New Jersey: John Wiley \& Sons, Inc. 
Hinton, C., Towell, J., MacFarlane, A., Refling, E., \& Amesbury, J. (2017). Student Success ePortfolio: Student, Faculty and Employer Perspectives on the value of ePortfolios in Assessing the Development of Essential Employability Skills. Higher Education Quality Council of Ontario.

Lievens, R. (2014). A proposal: Mitigating effects of the economic crisis with career ePortfolios. International Journal of ePortfolio, 4(2), 157-168. R Article retrieved from http://www.theijep.com/pdf/JJEP139.pdf

Mohamad, S. N. A., Embi, M. A., \& Nordin, N. M. (2016). Designing an E-portfolio as a Storage, Workspace and Showcase for Social Sciences and Humanities in Higher Education Institutions (HEls). Asian Social Science, 12(5), 185-194.

Morrison, K. (2015). Recruiters Use Social Media to Find High-Quality Candidates. Article retrieved from https://www.adweek.com/performance-marketing/survey-96-ofrecruiters-use-social-media-to-find-high-quality-candidates/

Muller. J. (2021) Social Media Users as a Percentage of The Total Population in Malaysia 2021. Article retrieved from https://www.statista.com/statistics/883712/malaysiasocial-media-penetration/

Pool, L. D., \& Sewell, P. (2007). The Key to Employability: Developing a Practical Model of Graduate Employability. Education And Training. 49 (4), $277-289$.

Watty K. \& McKay J., (2016). ePortfolios: What Employers Think. Article retrieved from https:/www.globalfocusmagazine.com/eportfolios-what-employers-think/ 